\title{
Ruminal degradation and in vivo digestibility of processed rapeseed meal
}

\author{
LIISA SYRJÄLÄ-QVIST, EEVA PEKKARINEN and JOUKO SETÄLÄ \\ Department of Animal Husbandry, University of Helsinki \\ SF-00710 HELSINKI 71, Finland
}

\begin{abstract}
The digestibility and nutritive value of rapeseed meal processed in different ways were studied with adult rams fed on alkali-treated straw. The rumen degradability was determined by the nylon bag technique. The rapeseed meal feeds were:

1) untreated rapeseed meal, 2) heat-treated rapeseed meal $\left(2-5 \mathrm{sec}\right.$. at over $\left.\left.100^{\circ} \mathrm{C}\right), 3\right)$ heattreated rapeseed meal $+5 \%$ urea phosphate and 4) heat-treated rapeseed meal $+10 \%$ rapeseed hulls.

The heat treatment reduced the rumen degradation and in vivo digestibility of the rapeseed meal, although not significantly $(\mathrm{P}>0.05)$. Addition of urea phosphate to the heattreated rapeseed meal increased the ruminal degradability of the crude protein and improved the digestibility of all the constituents of the rapeseed meal, especially that of crude fibre $(\mathrm{P}>0.05)$. The rapeseed hulls had no noticeable effect on digestibility.
\end{abstract}

\section{Introduction}

Rumen microbes need a certain amount of rumen-degradable crude protein for maximal protein synthesis and fermentation activity. When the feed contains insufficient rumen-degradable protein for the microbes, digestion and protein synthesis are reduced, but presence of this protein in excess of the need for microbial synthesis can decrease the utilization of protein.

Reduction of rumen-degradable protein has been shown to have a beneficial effect with high-production animals, whose protein requirement is great (ANON. 1978, KAUF-
MANN, 1979, ANON. 1980). For instance, milk production and protein utilization were improved in dairy cows, when part of the silage protein was replaced with rapeseed meal protein of lower rumen-degradability (SYRJÄLĀQvist and SETÃLÄ 1982). When untreated and formaldehyde-treated rapeseed meal was fed to high-production dairy cows, the treatment was found to reduce the ruminal $\mathrm{NH}_{3}-\mathrm{N}$ concentration, but did not reduce the digestibilities of dry matter, nitrogen or fibre (INGALls et al. 1983). Nor had it any effect on milk production.

The aim of the present experiment was to study the digestibility and nutritive value of 
rapeseed meal when it is untreated and when its ruminal degradability has been modified by heat treatment. The effect of adding urea phosphate or rapeseed hulls to the heattreated rapeseed meal was also examined.

\section{Experimental procedures}

The digestibility and nitrogen balance experiment was performed with four adult sheep according to a $4 \times 4$ Latin square. Each experimental period lasted two weeks, the second week being the total collection period. The rapeseed feeds used in experiment were as follows:

1) Untreated rapeseed meal
2) Heat-treated rapeseed meal $(2-5 \mathrm{sec}$. at over $100^{\circ} \mathrm{C}$ )

3) Heat-treated rapeseed meal $+5 \%$ urea phosphate

4) Heat-treated rapeseed meal $+10 \%$ rapeseed hulls

The basic feed was alkali-treated straw, whose digestibility was known (Table 1). Each diet consisted of $400 \mathrm{~g}$ rapeseed feed and $550 \mathrm{~g}$ straw per animal and day plus mineral and vitamin mixtures and water. The feeding procedures, feed sampling, analyses and calculations were as described by SYRJÄ. LĂ et al. (1978).

The ruminal degradability of the rapeseed meal feeds was determined by the nylon bag

Table 1. The mean chemical composition, digestibility and nutritive value of the different feeds.

\begin{tabular}{|c|c|c|c|c|c|}
\hline Feeds & $\begin{array}{l}\text { Untreated } \\
\text { rapeseed } \\
\text { meal }\end{array}$ & $\begin{array}{l}\text { Heat-treated } \\
\text { rapeseed } \\
\text { meal }\end{array}$ & $\begin{array}{c}\text { Heat-treated } \\
\text { rapeseed meal } \\
+ \text { urea } \\
\text { phosphate }\end{array}$ & $\begin{array}{l}\text { Heat-treated } \\
\text { rapeseed meal } \\
+ \text { hulls }\end{array}$ & $\begin{array}{c}\mathrm{NaOH}- \\
\text { treated } \\
\text { straw }\end{array}$ \\
\hline $\begin{array}{l}\text { Dry matter, } \% \\
\% \text { of dry matter: }\end{array}$ & \multicolumn{4}{|c|}{$\%$ of dry matter: } & 76.3 \\
\hline Ash & 7.7 & 7.5 & 9.2 & 7.4 & 10.6 \\
\hline Crude protein & 36.4 & 36.1 & 39.9 & 34.6 & 2.8 \\
\hline Crude fat & 3.8 & 4.2 & 4.0 & 5.6 & 0.8 \\
\hline Crude fibre & 14.6 & 14.7 & 14.1 & 15.4 & 46.5 \\
\hline $\mathrm{N}$-free extract & 37.5 & 37.4 & 32.7 & 37.0 & 39.3 \\
\hline \multicolumn{6}{|l|}{ Digestibility, \% } \\
\hline Dry matter & 75.1 & 71.9 & 74.8 & 73.5 & 57.4 \\
\hline Organic matter & 76.5 & 73.5 & 76.8 & 74.3 & 58.5 \\
\hline Crude protein & 79.7 & 78.4 & 81.3 & 77.7 & -30.0 \\
\hline Crude fat & 82.8 & 86.6 & 84.3 & 89.8 & 80.0 \\
\hline Crude fibre & 50.3 & 45.6 & 53.6 & 49.7 & 71.6 \\
\hline $\mathrm{N}$-free extract & 80.2 & 76.4 & 78.3 & 76.7 & 50.6 \\
\hline $\mathrm{N}$ balance, $\mathrm{g} /$ day & 2.1 & 1.6 & 1.9 & 1.7 & \\
\hline $\begin{array}{l}\mathrm{N} \text { secretion in urine, } \\
\% \text { of } \mathrm{N} \text { supply }\end{array}$ & 61.9 & 62.3 & 65.1 & 60.5 & \\
\hline $\begin{array}{l}\mathrm{N} \text { secretion in feaces, } \\
\% \text { of } \mathrm{N} \text { supply }\end{array}$ & 29.0 & 30.7 & 27.2 & 31.7 & \\
\hline kg/f.u. ${ }^{1}$ & 1.21 & 1.21 & 1.18 & 1.18 & \\
\hline DM kg/f.u. ${ }^{2}$ & 1.07 & 1.10 & 1.08 & 1.05 & \\
\hline DCP $\mathrm{g} / \mathrm{f}^{\mathrm{u}} .^{3}$ & $311^{\mathrm{a}}$ & $310^{a}$ & $350^{b}$ & $283^{a}$ & \\
\hline DCP $\%$ in DM & $29.0^{a}$ & $28.3^{\mathrm{a}}$ & $32.4^{b}$ & $26.9^{a}$ & \\
\hline
\end{tabular}

1 f.u. $=$ feed unit $=0.7$ starch equivalent

${ }^{2} \mathrm{DM}=$ dry matter

${ }^{3}$ DCP $=$ digestible. crude protein

Statistical analysis applied only to digestibilities and feeding values. Different index letters in a vertical column show that there are significant differences between the averages at the $99.9 \%$ levels of confidence. 
tehnique (Mehrez and ØrSKov 1977), as described by SETÃLÃ (1983). The incubation periods were 2, 5 and 9 hours and the sheep used in the experiment received $1.5 \mathrm{~kg}$ hay per day.

\section{Results and discussion}

The heat-treatment decrease the in vivo digestibility of all the components of the rapeseed meal except that of crude fat (Table 1). The differences were, however, not significant $(\mathrm{P}>0.05)$. Addition of urea phosphate to the heat-treated rapeseed meal improved the apparent digestibility, especially that of crude fibre, but not significantly. Addition of rapeseed hulls to the heat-treated rapeseed meal had also no significant effect.

The nitrogen balance of the sheep in different diets and the results describing the energy value of the different rapeseed feeds were about the same (Table 1).

In the untreated rapeseed meal the ruminal degradability of crude protein, organic matter and dry matter remained at the same level, about $40 \%$ during the incubation periods of 2 and 5 hours, but after 9 hours it had increased to 56-58\% (Fig. 1). These values are about the same as those obtained for crude protein in other studies, (ANON. 1982, Setälä and Syrjälä-Qvist 1982), or lower (MAthers et al. 1977, ANON. 1980). The method used in removing oil from seeds has been shown to affect the ruminal protein degradation (JOSEFFSON 1972) and this can be one reason for the variation in the results of different experiments. Heat treatment of the feeds has also been shown to decrease the degradation of feed protein in the rumen (Mehrez and Ørskov 1977). In this experiment the degradation of crude protein with heat-treated rapeseed meal without urea phosphate was lower than with untreated meal during the incubation periods of 2 and 9 hours, but not during the incubation period of 5 hours. With heat-treated rapeseed meal the degradation of crude protein after 2, 5 and 9 hours incubation was 22,43 and

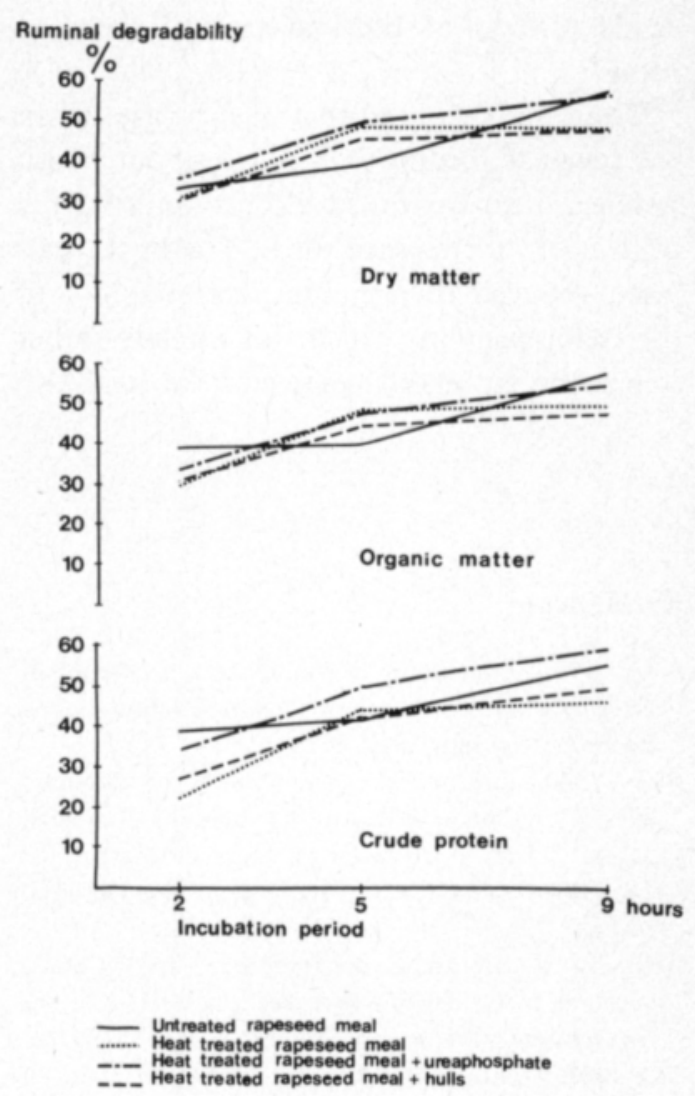

Fig. 1. Ruminal degradability of the rapeseed feeds in different incubation periods.

$46 \%$, respectively, and with untreated rapeseed meal it was 39,41 and $55 \%$. Hence heat treatment slightly affected the rate of protein degradation in the rumen.

When the heat-treated rapeseed meal contained urea phosphate, the degradation of crude protein in the 2,5 and 9 hour incubation periods was 12,7 and $13 \%$ units higher than with heat-treated rapeseed meal. The values were higher than those of untreated rapeseed meal in the incubation periods of 5 and 9 hours. The reason is the high solubility of urea in the rumen, though the rate of urea degradation is slown down when urea is given as urea phosphate (e.g. McQUEEN et al. 1980).

Addition of rapeseed hulls did not have any marked effect on the ruminal degradability of the dry matter, organic matter or 
crude protein of the heat-treated rapeseed meal.

The results showed that in this case, when the level of feeding was set at about maintenance, heat treatment did not improve the utilization of rapeseed meal. The heat treatment reduced the ruminal degradability of the crude protein, which was already rather low in the untreated rapeseed meal, and also tended to decrease the in vivo digestibility. As the heat-treated rapeseed meal was the only protein source, the rumen microbes probably did not have enough rumen-degradable protein for maximal activity, which led to reduced rumen fermentation activity. This conclusion is supported by the positive effect of urea on the digestibility of crude fibre.

\section{References}

ANon. 1978. Alimentation des Ruminants. INRA publications, Route de Saint-Gyr. Institut National de la Recheche Agronomique. 597 p.

ANON. 1980. The nutrient requirements of ruminant livestock. Commonwealth Agricultural Bureaux. $351 \mathrm{p}$.

ANON. 1982. Rehutaulukot ja ruokintanormit. Helsinki. $70 \mathrm{p}$.

Ingalls, J. R., RAE, R. C. \& Chase, L. E. 1983. Canola meal and formaldehyde treated canola meal in rations for lactating cows. International Rapeseed Conference 1983: 1558-1562. Paris.

JosEFsson, E. 1972. Nutrition value and use of rapeseed meal. Rapeseed cultivation, composition, processing and utilization ed. Appelquis, L-Ả. \& Ohlsson R. p. 354-375. Elsvier, Amsterdam and London.

KaufMann, W. 1979. Zur Eiweissverdauung bei Wiederkăuern im Hinblick auf die faktorielle Berechnung des Eiweissbedarfes. Z. Tierphys.Tierernăhr. u. Futtermittelk. 42: 326-333.

Mathers, J. C., Horton, C. M. \& Miller, E. L. 1977. Rate and extent of protein degradation in the rumen. Proc.Nutr.Soc. 1977: 37A.

Mcqueen R. E., Seoane J. R., Nicholson J. W. G. \&

Mcrae K. B. 1980. Effect of urea phosphate, ureaform or urea on rumen and blood ammonia. Can. J. Anim. Sci. 60: 572.

Mehrez, A. Z. \& Ørskov, E. R. 1977. A study of the artificial fibre bag techique for determining the digestibility of feeds in rumen. J.Agric.Sci., Camb. 88: 645-650.

SETÃLĀ, J. 1983. The nylon bag technique in the determination of ruminal feed protein degradation. J.Scient.Agr.Soc.Finl. 55: 1-78.

SetÃlä, J. \& SYrJÁlĀ-Qvist, L. 1982. Ruminal degradation of protein of processed rapeseed. EAAP Congress. Leningrad. $5 \mathrm{p}$.

Syrjălä-Qvist, L. \& Setälä, J. 1982. Comparison of grass silage, soybean and rapeseed as protein sources in dairy cow feeding. EAAP Congress. Leningrad. $5 \mathrm{p}$.

SYruĀlä, L., Syvãoja, E.-L. \& Boman, M. 1978. Utilization of untreated and formaldehyde treated skimmilk powder and skimmilk powder-barley pellets by ruminants. J.Scient.Agric.Soc.Finl. 50: 166-176.

Ms received April 12, 1984 . 


\section{SELOSTUS}

\section{Prosessoidun rypsirouheen pötsihajoavuus ja in vivo sulavuus}

\section{Liisa Syrjälä-Qvist, Eeva Pekkarinen ja Jouko Setälä}

Helsingin yliopisto, kotieläintieteen laitos, 00710 HELSINKI 71

Lipeảolkea perusrehuna saaneilla tăysikasvuisilla pässeillă maaaritettiin erilaisten rypsirehujen sulavuus ja ruokinta-arvo sekă heinăruokinnalla olleella pässillä samojen rypsirehujen pötsihajoavuus. Kokeissa käytetyt rypsirehut olivat seuraavat: 1) tavallinen rypsirouhe, 2) lämpökäsitelty rypsirouhe (2-5 sek. yli $\left.\left.100^{\circ} \mathrm{C}: s s a\right), 3\right)$ lămpökäsitelty rypsirouhe $+5 \%$ ureafosfaattia, 4) lămpökäsitelty rypsirouhe $+10 \%$ rypsinsiementen kuoria.

Låmpökảsittely vähensi rypsirouheen pötsihajoavuut-

ta sekă alensi in vivo sulavuutta. Pötsimikrobistolle tuli tăllöin todennäköisesti puutetta typellisistă aineista, mikä tässă kokeessa käytetyillä ruokinnoilla johti mikrobiaktiviteetin heikkenemiseen ja edelleen sulavuuden alenemiseen. Tătă osoitti myős se, ettả lisăttäessä ureafosfaattia lämpökäsiteltyyn rouheeseen, pötsissă hajoavan valkuaisen osuus lisääntyi ja samalla myös sulavuus, varsinkin kuidun sulavuus parani. Siemenkuorilla sen sijaan ei ollut sanottavaa vaikutusta sulavuuteen. 